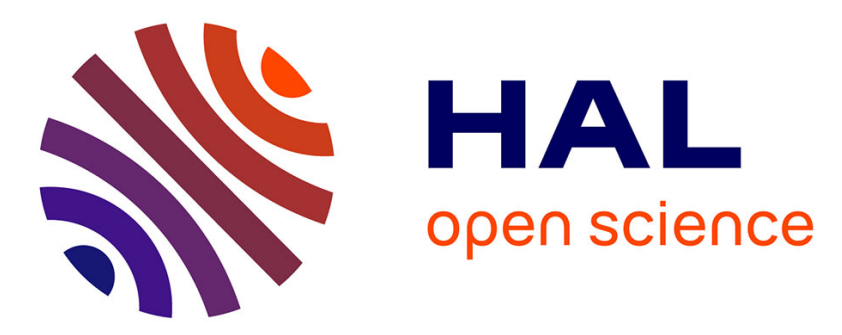

\title{
GEREM (Glass Eel Recruitment Estimation Model): A model to estimate glass eel recruitment at different spatial scales
}

\author{
Hilaire Drouineau, C. Briand, Patrick Lambert, Laurent Beaulaton
}

\section{To cite this version:}

Hilaire Drouineau, C. Briand, Patrick Lambert, Laurent Beaulaton. GEREM (Glass Eel Recruitment Estimation Model): A model to estimate glass eel recruitment at different spatial scales. Fisheries Research, 2016, 174, pp.68-80. 10.1016/j.fishres.2015.09.003 . hal-01706769

\section{HAL Id: hal-01706769 \\ https://hal.science/hal-01706769}

Submitted on 12 Feb 2018

HAL is a multi-disciplinary open access archive for the deposit and dissemination of scientific research documents, whether they are published or not. The documents may come from teaching and research institutions in France or abroad, or from public or private research centers.
L'archive ouverte pluridisciplinaire HAL, est destinée au dépôt et à la diffusion de documents scientifiques de niveau recherche, publiés ou non, émanant des établissements d'enseignement et de recherche français ou étrangers, des laboratoires publics ou privés. 
1 GEREM (Glass Eel Recruitment Estimation Model): A model to estimate glass eel recruitment at different spatial scales

3 Authors: Drouineau, H. ${ }^{1, *}$; Briand, C. ${ }^{2}$; Lambert, P.'; Beaulaton, L. ${ }^{34}$

4

51 Irstea UR EABX, 50 avenue de Verdun, centre de Bordeaux, F-33612 Gazinet Cestas,

6 France

72 Institution Aménagement de la Vilaine, 56130 La Roche-Bernard, France

83 Onema, Pôle Gest'Aqua, 65 rue de St Brieuc, 35042 Rennes, France

94 INRA, U3E (1036), Pôle Gest'Aqua, 65 rue de St Brieuc, 35042 Rennes, France

$11 *$ corresponding author: hilaire.drouineau@irstea.fr, tel: +33 (0)5 578927 09, fax :+33 (0)5

1257890801

\section{Abstract}

14 Given the importance of reliable recruitment estimates when assessing temperate eel stocks

15 and enforcing appropriate management measures, surprisingly few analytical tools have been

16 developed to estimate yearly glass eel recruitment. Of the models that do exist, large-scale

17 models generally rely on strong assumptions relating to fishing activity, while other models

18 generally estimate recruitment at the river basin scale. With the aim of filling this gap, we

19 developed the GEREM (Glass Eel Recruitment Estimation Model) to estimate glass eel

20 recruitment at different nested spatial scales. Our model simultaneously estimates annual

21 recruitment at river catchment level, at an intermediate spatial scale such as Eel Management

22 Units (EMUs), and at a larger scale (e.g. a country). Provided enough data become available

23 in the future, the analysis could be extended to the scale of the distribution area, which would

24 be consistent with the population scale. In this study, the model was applied to France, using 
25 various recruitment indices obtained from 1960 to 2013. This provided trends and absolute

26 recruitment estimates consistent with current expert knowledge. A sensitivity analysis was

27 carried out to assess the robustness of results to sources of uncertainty. This type of model

28 fills an important gap in the range of quantitative tools presently available to estimate

29 recruitment. It could be used in the future to fix total allowable catches in countries such as

30 France where glass eels are fished commercially.

32 Keywords: Anguilla anguilla, temperate eel, recruitment, stock-assessment model, glass eel

\section{$34 \quad 2 \quad$ Introduction}

35 The European eel (Anguilla anguilla) is a catadromous species whose population spans a vast

36 area, stretching from Morocco to Norway (Tesch, 2003). Reproduction takes place in the

37 Sargasso Sea (Schmidt, 1923), after which leptocephalus larvae are passively transported by

38 oceanic currents to the continental shelf, where they metamorphose into glass eels (Tesch,

39 2003). They then enter continental waters, becoming pigmented glass eels and later yellow

40 eels. Yellow eels grow in freshwater or estuarine habitats, typically for 3 to 15 years

41 (Vollestad, 1992), after which they metamorphose into silver eels and achieve sexual maturity

42 while migrating back to spawning grounds.

43 The European eel population has been in drastic decline since the late 70s (Castonguay et al.,

44 1994; Dekker, 2003; Dekker et al., 2003; Dekker and Casselman, 2014). The IUCN lists $A$.

45 anguilla as "critically endangered" (Jacoby and Gollock, 2014). Many possible reasons for

46 this population collapse have been suggested, including changes in oceanic conditions

47 (Castonguay et al., 1994), contamination and habitat degradation, parasitoids (Feunteun,

48 2002), fishing pressure, and massive habitat loss (Kettle et al., 2011). 
49 In the late 2000s, the European Commission introduced Regulation $N^{\circ} 1100 / 2007$, imposing a

50 new set of measures designed to reverse the decline. Because eels spend most of their growth

51 phase in continental waters, implementing these measures was (and remains) the

52 responsibility of EU member states. Under the new rules, member states were required to

53 create Eel Management Units (EMUs). An EMU is a homogeneous group of river basins that

54 are home to eels, and where specific protective measures are applied. These measures are

55 referred to as Eel Management Plans (EMPs). In 2008, each EU Member State submitted its

56 proposed EMUs and EMPs for approval by the EU Commission.

57 Though management measures are implemented at the national and regional scales, the stock

58 is assessed at the population scale which corresponds to the distribution area since genetic

59 evidence demonstrates that the European eel is totally panmictic (Als et al., 2011).

60 Assessment is carried out yearly by the joint EIFAAC (European Inland Fisheries and

61 Aquaculture Advisory Commission), ICES (International Council for the Exploration of the

62 Sea) and GFCM (General Fisheries Commission for the Mediterranean) working group on

63 eels (WGEEL).

64 Several abundance indices are collected for stock assessment: recruitment indices, yellow eel

65 abundance indices and silver eel catches. Aside from the questionable quality of some of these

66 data, the fractal dimension of eel stock (Dekker, 2000b) makes it difficult to interpret yellow

67 and silver eel indices. During their growth stage, eels are subject to contrasted environmental

68 conditions (distribution area ranging from Morocco to Norway) and anthropogenic pressures

69 (fishing activity, hydropower mortality, contaminate, etc.) which are difficult to assess at

70 European level (Dekker, 2000). Also, eels display a marked contrast in life-history traits and

71 tactics at the river basin and distribution area scales (Drouineau et al., 2014). This includes

72 sex-ratio (Kettle et al., 2011) and age-at-silvering (Vollestad, 1992), which can vary from 3

73 years in southern Europe to over 20 in northern Europe. In view of this, it is very difficult to

74 distinguish between local effects and stock status when analysing yellow and silver eel 
75 indices. Another issue is that commercial silver eel fishing only takes place in a handful of

76 European regions, and relevant effort data are rarely reported, making silver eel catches

77 difficult to interpret. In view of this, WGEEL considers that while yellow and silver eel

78 indices may be used in the future, they are currently too scarce and uncertain and may be

79 more representative of the local area where they are collected than of overall eel stock (ICES,

80 2014). On the other hand, glass eels correspond to the first continental stage and are

81 consequently less influenced by local conditions. Several monitoring projects throughout

82 Europe are dedicated to glass-eels. They use sampling methods adapted to this specific eel

83 stage (specific commercial and scientific fishing gear, glass-eel ladder, etc.). In 2002, a

84 European project was set up to list and co-ordinate these monitoring programs (Dekker,

85 2002).

86 For the reasons stated above, recruitment indices are of major importance in assessment. They

87 may also be used to assess "non-detriment findings" (CITES) for the issue of export permits,

88 as proposed by ICES (2015). A series of indices is available for sites across Europe. These are

89 analysed by the WGEEL on a yearly basis, and further summarised in three separate indices

90 (ICES, 2013). Two of these indices report glass eel trends, one in the North Sea, and the other

91 for the rest of Europe (referred to as "Elsewhere Europe"). A third index reports trends for

92 young yellow eels, mostly in the Baltic Sea (ICES, 2013).

93 Recruitment estimates are especially important for countries such as France, where glass eels

94 are commercially fished (silver eels can only be fished in the Loire River and in the south of

95 the country, while commercial yellow eel fishing is much less widespread), meaning that

96 quantitative tools are needed to set permitted glass eel quotas (it should be noted that the

97 equipment used to catch glass eels is completely different from that used to catch silver and

98 yellow eels). In the late 90's, glass eel fishing was important in France (Briand et al., 2008).

99 At that time, eel was the most important species landed in value in the Bay of Biscay

100 (Castelnaud, 2001). In some specific river basins, fishing impact was very high with 
101 exploitation rates over 95\% (Briand et al., 2003). In view of this, models such as GEMAC

102 (Beaulaton and Briand, 2007), or a model developed by Bru et al. (2006) and Prouzet et al.

103 (2007), have been developed to estimate exploitation rates and recruitment at catchment scale.

104 However, one disadvantage of these models is that they only work at an estuarine scale. From

105 an EU perspective, it would be desirable to have a model capable of estimating recruitment

106 across the entire EMU, or even the whole of Europe. In this paper, we present GEREM (Glass

107 Eel Recruitment Estimation Model): a Bayesian model to estimate recruitment at various

108 nested spatial scales. A hierarchical Bayesian model is one of the most suitable types of model

109 when dealing nested spatial scales. It allows recruitment at large scales to be inferred from

110 observations carried out at smaller scales. The Bayesian approach also makes it possible to

111 incorporate prior information, as well as quantifying uncertainty. To illustrate the model's

112 potential, we provide the results of an initial test on French EMUs. The possibility of using

113 the model at European level is then discussed.

\section{Material and methods}

\section{$116 \quad 3.1$ Model description}

117 3.1.1 State models: assumptions relating to recruitment at different spatial scales

118 The model aims to estimate yearly absolute recruitment of glass eels using recruitment data

119 collected from various river catchments. The model uses three nested spatial scales:

120 - The overall recruitment: $R(y)$ glass eel within the whole study area year $y$. The study

$121 \quad$ area is composed of $N_{z}$ zones.

122 - Zonal recruitment: $R_{z}(y)$ glass eel within a zone $z$. A zone is a homogeneous sub-

123 section of the study area, made up of various river catchments in which glass eel

124 density is assumed to be similar. Each zone is composed of $n_{z}$ river catchments, each 
with its own surface area: $S_{1, z}, \ldots, S_{n_{z}, z}$. Catchment surfaces were recorded in the

- $\quad$ River catchment recruitment $R_{c, z}(y)$ : glass eel over a river catchment $c$, which is located in zone $z$ and is characterised by its catchment surface $S_{c, z}$.

130 We assume that the overall recruitment $R(y)$ is divided into different recruitment zones based

131 on a multinomial distribution, with proportions $p_{z}$ for each zone. This multinomial distribution

132 mimics the random passive distribution of leptocephali generated by oceanic currents. The

133 multinomial distribution is approximated by marginal normal distributions (Johnson et al.,

134 1997):

$$
R_{z}(y) \sim \operatorname{Normal}\left(R(y) \cdot p_{z}, R(y) \cdot p_{z} \cdot\left(1-p_{z}\right)\right)
$$

136 Similarly, zonal recruitment is divided into river catchments according to a multinomial

137 distribution with proportions equal to a function of their relative surface area within the zone.

138 As in the previous split level, the multinomial distribution is approximated by marginal

139 normal distributions (Johnson et al., 1997):

140

$$
R_{c, z}(y) \sim \operatorname{Normal}\left(R_{z}(y) \cdot w_{c, z}, R_{z}(y) \cdot w_{c, z} \cdot\left(1-w_{c, z}\right)\right)
$$

141 The weight $w_{c, z}$ of each catchment is calculated as a power function of its surface:

$$
w_{c, z}=\frac{S_{c, z}^{\beta}}{\sum_{c_{2}=1}^{n_{z}} S_{c_{2}, z}^{\beta}}
$$

143 A $\beta$ value close to 1 would mean that recruitment is proportionate to catchment surface, which

144 can be considered a proxy of available habitat. However, it has previously been observed (at

145 least on small catchments) that river discharge and river plume have an influence on glass eel

146 recruitment (Crivelli et al., 2008; Elie and Rochard, 1994). If river discharge is the main

147 factor influencing the proportions in each catchment, then the power is less than one. This is 
148 shown by a meta-analysis carried-out by Burgers et al. (2014), which demonstrates that river

149 discharge is a power function of catchment surface with a power less than 1. A power greater

150 than 1 would imply an over-concentration of glass eels in large catchments. However, this is

151 unlikely, because it would be inconsistent with large commercial catches in small catchments.

152 The overall recruitment is assumed to follow a random walk:

153

$$
R(y)=R(y-1) \cdot e^{\epsilon(y)} \text { with } \epsilon(y) \sim \operatorname{Normal}\left(0, \sigma_{R}^{2}\right)
$$

\subsubsection{Observation model}

156 Two types of observed time series are used to fit the model:

$157 I A_{i, c}(y)$ denotes a relative abundance index $i$ observed in a catchment $c$, which is assumed to

158 be lognormally distributed:

$$
\log \left(I A_{i, c}(y)\right) \sim N\left(\mu_{I A_{i, c}}(y), \sigma_{I A_{i}}^{2}\right) \text { with } \mu_{I A_{i}}(y)=\log \left(q_{i} \cdot R_{c, z}(y)\right)-\frac{\sigma_{I A_{i}}^{2}}{2}
$$

160 with $q_{i}$ a scale factor.

$161 U_{i, c}(y)$ denotes an absolute recruitment estimate series (or a punctual estimation) $i$ observed in

162 a catchment $c$, which is also assumed to follow a lognormal distribution:

$$
\log \left(U_{i, c}(y)\right) \sim N\left(\mu_{U_{i, c}}(y), \sigma_{U_{i}}^{2}\right) \text { with } \mu_{I A_{i}}(y)=\log \left(R_{c, z}(y)\right)-\frac{\sigma_{U_{i}}^{2}}{2}
$$

165 The model requires at least an absolute index (a series or a punctual estimate) per zone to be

166 identifiable: without any absolute index in a zone, the corresponding recruitment zone and

167 consequently the overall recruitment would only be relative estimates. 


\section{3.1.3 Bayesian inference}

170 The model is fitted using Stan (Stan Development Team, 2013), a package to obtain Bayesian

171 inference via the No-U-Turn sampler, a variant of the Hamiltonian Monte Carlo, and rstan, an

172 R (R Development Core Team, 2011) interface to Stan. Uninformative or flat priors are used

173 for most parameters (Table 1). For $\gamma$, which is often called Dirichlet concentration parameter

174 (a value below 1 leads to sparse distributions while a value above 1 leads to dense

175 distributions), we used an uninformative prior recommended by (Ohlssen et al., 2007). For $\beta$,

176 used a uniform prior between 0.01 and 2 because, as previously mentioned, a $\beta$ above 1 is

177 unlikely.

\section{$179 \quad 3.2$ Application to French eel substock}

180

181

182

183

184

185

186

187

188

189

190

191

\subsubsection{EMU description}

The model was applied to France. As part of the French eel management plan (Anonymous, 2010) 9 EMUs were defined. In this study, the Rhine-Meuse EMU was discarded, as recruitment does not occur in the French part of this EMU. The Artois-Picardy and Corsica EMUs were merged with the Seine-Normandy and Mediterranean EMUs respectively, as no data were available for the Artois-Picardy and Corsica EMUs. These six (merged) EMUs (Table 2 and Fig. 1) are the six zones from the model $\left(N_{z}=6\right)$.

\subsubsection{Recruitment indices}

Thirteen series, collected in nine different catchments, were used in this study (Table 3). Of those, eight represent an absolute number of recruits. The characteristics of the nine corresponding catchments are provided in Table 3.

92 Seven of those data-series (Vil, Loi, SevN, GiS, GiCP, AdCP, Brel) are currently used by the 
193 WGEEL - along with 19 other European series - to derive the Elsewhere-Europe index (ICES,

194 2014).. Seven data-series covering France are presented by Feunteun et al (2002). Three main

195 types of data were considered as relative indices: (i) commercial catch divided by fishing

196 effort (SevN, GiCP, AdCP) (except for the Loi index for which no effort data were available

197 but catch data were consistent with CPUE from other series), (ii) a scientific index from a

198 standardized monitoring program (GiSc), and (iii) yearly counts in a scientific fish trap (Bres).

199 Fishery-based indices only go as far as 2011. Since 2011, fishing activity in France has been

200 extensively modified due to the introduction of a new quota system. Consequently, fishery-

201 based indices taken before and after these changes cannot be effectively compared.

202 The model also requires absolute estimates. These were obtained using three methods:

ChGEMAC, SeGEMAC, GiGEMAC, are recruitments estimates provided by GEMAC (Beaulaton and Briand, 2007) while AdGERMA and LoGERMA are recruitment estimates provided developed by Bru et al.'s model $(2006,2009)$. The two models were developed to estimate commercial exploitation rates at the river basin scale. They are essentially based on an estimation of glass-eel density based on catches divided by sampled volume, which is then multiplied by the total volume of the zone. The GEMAC model uses either commercial or scientific catches, while the Bru et al. (2009) model requires the use of scientific catches to estimate glass eel daily were statistically independent, even though they came from similar models. at a trapping ladder located at an impassable dam in the Vilaine estuary (Briand, 2008). Commercial fishing takes place just downstream from the dam, where glass eels aggregate. Statistical analysis shows that commercial fishery is so efficient (over 
95\%) that total catches can be used to estimate total recruitment (Briand et al., 2003). catch, and this series is closest to the average of the "Elsewhere Europe" recruitment series (ICES, 2010). Local conditions are fairly similar in the Somme, where that it provided an absolute estimate of total recruitment. commercial fishing also takes place downstream from an estuarine dam. On the basis that glass eels were also blocked by this obstacle, an expert-estimated exploitation rate of $75 \%$ was used, although no in-depth analysis was carried out (contrary to the Vilaine estuary). Consequently, we multiplied this data-series by 1.33 and assumed from a fish pass. The fish pass is located on a sea wall which blocks the sea channel (Crivelli et al., 2008).

231 Absolute indices are expressed in tonnes of glass eels, while relative indices are standardised

232 according to their mean values. The model was fitted to the period 1960-2013. Three chains

233 were run independently in parallel for 10,000 iterations after a burn-in period of 10,000

234 iterations. Convergence was checked using Gelman-Rubin diagnostics (Gelman and Rubin, 235 1992).

\subsection{Sensitivity analysis}

238 The model relies on two main assumptions: (i) absolute recruitment indices are unbiased

239 estimates of real recruitment and (ii) catchment recruitment is derived from zone recruitment 240 with a power function of the catchment surface. Two complementary analyses were carried 241 out to test the influence of those assumptions on the results of the model:

242 - S1 addresses the consequences of a systematic bias in absolute recruitment indices.

243 The model was fitted successively to 8 altered datasets - one dataset per absolute 
recruitment index. For each dataset, the absolute recruitment estimate was multiplied

by 1.1 to mimic a systematic bias of $10 \%$. Underestimation was considered more case, our data underestimate the true value and should be multiplied by a correction factor superior to 1 .

- $\quad$ S2 assesses the influence of extrapolation (equation 2). The model was fitted after fixing $\beta$ at three different values: $0.5,1$ and 1.5 .

\section{Results}

\section{$255 \quad 4.1$ Recruitment estimates}

256 Gelman and Rubin diagnostics confirmed that the chain converged after 20,000 iterations

257 (10,000 burn-in+10,000 samples for inference). $\quad \bar{R}$ statistics were less than 1.05 for all

258 parameters (Table 1).

259 A visual inspection of the results confirmed that prior distributions had limited influence on

260 posterior distributions (see supplementary materials). The posterior distribution of $\gamma$ was

261 limited by the right bound of the prior distribution. However, allowing for a larger Dirichlet

262 concentration parameter would lead to denser Dirichlet distributions, resulting in more

263 informative priors on $p_{z}$, which are not suitable.

264 The model fitted well both relative abundance and absolute abundance indices (Fig. 2 and Fig.

265 3). Observed data were generally within credibility intervals. As expected, large credibility

266 intervals were occasionally observed for series with missing data. However, since all of the

267 data series were relatively consistent, missing data from a series were made up for by data 
268 from other series, resulting in small credibility intervals for most series. Larger credibility

269 intervals were observed for Somme, Vaccares, Bres, and SeGEMAC in certain years. For

270 those catchments, recruitment values were low, either because of a small catchment surface or

271 because the catchment was located in a zone where glass eels were scarce. As a consequence,

272 recruitment $R_{c, z}(y)$ was very low (close to zero) and the normal approximation (equation 2)

273 sometimes led to very small values (even negative), resulting in large credibility intervals in

274 the logarithmic scale (since $\log (0)$ tends to negative infinity).

275 The overall glass eel recruitment estimated by the model was consistent with existing

276 knowledge and strongly correlated to the "Elsewhere Europe" index estimated by the WGEEL

277 (Fig. 4 - Kendall $\tau=0.87$ ). The model confirms that recruitment has been on the decline since

278 the late 70 s, following a period of stability during the 60 s and the 70 s. Recruitment was

279 relatively stable at around 4,000 tonnes before 1980 and then dramatically decreased to

280 approximately 140 tonnes in recent years, i.e. less than $5 \%$ of the recruitment which was

281 observed before the 80 s.

282 The estimated value of the overall recruitment divided by the surface of the studied area was

$2830.36 \mathrm{~kg} / \mathrm{km}^{2}$ (credibility interval: $[0.19,1.26]$ ) in 2010 . The ratio was equal to $0.75 \mathrm{~kg} / \mathrm{km}^{2}$ in

2842005 and $0.68 \mathrm{~kg} / \mathrm{km}^{2}$ in 2006. As a comparison, Cicotti (2006) estimated a ratio of around

$2850.01 \mathrm{~kg} / \mathrm{km}^{2}$ in the Tiber River (Italy) in the same period, while Aranburu et al. (in Press)

286 estimated a ratio of $1.68 \mathrm{~kg} / \mathrm{km}^{2}$ in the Oria River (Spain, Basque Country) in 2013.

287 The estimated catch rates oscillates between $20 \%$ and $30 \%$ from 1980 to 2010 with no

288 particular trend (Fig. 4) .

289 Recruitment is concentrated within three main EMUs: the Loire (median 34.6\%), Brittany

290 (median 26.0\%) and the Garonne (median 25.0\%) (Fig. 5).

291 The power coefficient $\beta$ credibility interval is large (median 0.51 , credibility interval $292[0.21,0.75])$ but significantly lower than 1. 


\section{$294 \quad 4.2$ Sensitivity analysis}

295 Whatever the scenario (S1 or S2), the estimated trend in the overall recruitment remained

296 similar (Fig. 6). However, the value of $\beta$ (S2) had a larger influence on results. Recruitment

297 was approximately $25 \%$ lower when setting $\beta$ at 1 than when it was set at 0.5 (close to our

298 estimated value). However, it was approximately 4.57 times higher when $\beta$ was set at 1.5 (but

$299 \beta$ greater than 1 are unlikely).

300 S1 had a limited impact on the distribution of recruitment among the different zones (Fig. 7).

301 The change mostly concerned the zone in which the altered series was collected, but remained

302 small when compared to credibility intervals. Interestingly, changes to one of the three

303 absolute estimates collected in the Garonne zone (GiGEMAC, ChGEMAC, SeGEMAC) did

304 not cause a large variation in $\beta$. $\beta$ was slightly lower when SeGEMAC (smallest catchment)

305 was modified (Fig. 8). As a consequence, the changes in the Garonne zone had limited impact

306 on recruitment in other zones (Fig. 7).

$307 \beta$ was the parameter with the largest influence. Changes mostly affected three zones: Brittany,

308 Garonne and Rhone-Mediterranea-Corsica. Estimated recruitment for Brittany decreased as $\beta$

309 increased, while, conversely, it increased for the Rhone-Mediterranea-Corsica zones.

310 Unsurprisingly, sensitivity to $\beta$ tended to decrease for zones where absolute estimates were

311 collected from the largest catchments in each zone (Table 3). It explains the difference in

312 variation of $\beta$ between Brittany and Rhone-Mediterranea-Corsica and Seine-Artois: for the

313 Brittany zone, the absolute estimate was collected in the largest catchment of the zone (the

314 Vilaine) whereas it was collected in relatively small catchments for the two other zones

315 (Vaccarès is a $6.5 \mathrm{~km}^{2}$ catchment in a $129,586 \mathrm{~km}^{2}$ zone, and the Somme is a $6,550 \mathrm{~km}^{2}$

316 catchment in a 114,293 $\mathrm{km}^{2}$ zone). For the Garonne zone, absolute indices were collected in

317 both large and small catchments resulting in a less straightforward response. 


\section{Discussion}

\section{$320 \quad 5.1$ GEREM - a model to fill a gap in the range of existing quantitative assessment tools}

321 The GEREM model addresses the estimation of absolute glass eel recruitment at various

322 nested spatial scales. As such, it provides new insights into eel recruitment dynamics, the

323 fractal nature of which is highlighted by Dekker (2000b). Glass eel recruitment is equally

324 fractal. Because it covers the entire eel population, the distribution area is the most

325 appropriate spatial scale when for stock assessment. Analysing recruitment at EMU scale is

326 consistent with the spatial management scale, while the river basin scale is consistent with

327 anthropogenic pressures (fishing activity, hydropower production, level of contamination,

328 habitat degradation) and the scale of data collection.

329 Assessing glass eel recruitment is essential for stock management (Moriarty and Dekker,

330 1997). Many traditional reference points used in fisheries management are based on stock-

331 recruitment relationships, and therefore require a recruitment time-series. Current limitations

332 stemming from the interpretation of yellow and silver eel indicators make recruitment indices

333 even more crucial when assessing the status of eel stocks (ICES, 2013). The procrustean

334 model proposed by Dekker (Dekker, 2000a) estimates recruitment at stock level, requiring

335 strong assumptions about the stability of recruitment and fishing activity (Dekker notably

336 assumed that silver eel catch rates and life cycle duration were similar in the whole

337 distribution area and that catches were known without errors). On the other hand, GEMAC

338 (Beaulaton and Briand, 2007) provides recruitment estimates at the catchment scale, but

339 cannot be applied at a larger spatial scale. GEREM fills a gap within the existing range of

340 tools by providing estimates at spatial scales consistent with biological and management

341 scales. In Europe, these scales may be used in the future to fix total allowable catches in

342 countries like France, where glass eels are fished commercially. 
343 The modelling approach used in GEREM could form the basis for a patch-based population

344 dynamics model (Wu and Levin, 1997) for the whole eel continental phase, similar to the

345 model currently being developed by Koops et al. (2014). In such a patch-based model, the

346 recruitment zones we have proposed may be subdivided into smaller patches that would be

347 homogeneous in terms of eel sub-population characteristics and anthropogenic pressure. In

348 those sub-patches, a simple stage-based model similar to the model proposed by Dekker

349 (2000a) could be applied using GEREM recruitment estimates for each patch and

350 incorporating new fishing effort data that were recently reconstructed by the WGEEL (ICES,

351 2013). The nested spatial scales, ranging from distribution area to recruitment zones,

352 subpatches, and river catchments would appear to be especially relevant in addressing the

353 fractal geometry of the eel population (Dekker, 2000b).

\subsection{Rationales of underlying assumptions and robustness of results}

356 To estimate absolute recruitment, the model is based on an assumption of two nested

357 multinomial distributions of the overall recruitment. At the finest spatial scale, the proportion

358 of recruitment in each river catchment is assumed to be a function of its surface area raised to

359 a power $\beta$. Currently, the model estimates for the $\beta$ parameter encompasses the power

360 coefficient of the relationship between maximum discharge and catchment area estimated by

361 Burgers et al. (2014), i.e. [0.57-0.69]. However, the estimation is only based on three series

362 (SeGEMAC, GiGEMAC and ChGEMAC) from the Garonne zone, which was the only zone

363 where more than one river basin absolute abundance estimate was provided.

364 The estimation of $\beta$ raises the question of how glass eels heading for coastal environments

365 navigate at sea, and whether they distribute themselves according to river flows or simply at

366 random in the area of their arrival. European leptocephalus larvae generally metamorphose

367 into glass eels when they cross the continental slope (Tesch, 2003). They use tidal (Tesch, 
368 2003) and wind driven currents (Westerberg, 1998) to progress towards the coast.

369 Experiments have shown that energy reserves and highly efficient swimming of American

370 glass eels allow them to sustain active swimming over long distances (Wuenschel and Able,

371 2008). Glass eels possess an acute sense of smell (Sorensen, 1986; Tesch, 2003) which is

372 thought to allow them to identify freshwater plumes and navigate as they approach the coast.

373 The final distribution of glass eels is the result of two mechanisms. The first is passive

374 transport by currents, which is described in the model by the first multinomial distribution

375 between different zones. The second is active navigation within a zone, which is probably

376 achieved by active migration but also the use of the tidal currents, which is described by the

377 second multinomial distribution.

378 The model is very sensitive to the value of $\beta$. Therefore, including more series with absolute

379 recruitment, or at least indices with standardised protocols and similar catchability values,

380 could significantly improve the model's estimates, as well as helping to work out the

381 relationship between catchment recruitment and catchment surface area. In the French

382 Management Plan, 10 “index rivers” have been identified (Anonymous, 2010) Within these

383 areas, specific efforts are made to quantify yearly eel recruitment and escapement. This ought

384 to provide valuable data in the near future. In the absence of any further data, comparing

385 model estimates with different values of $\beta$ could suffice. In our case study, the trend remained

386 similar, irrespective of $\beta$ values. However, overall recruitment was sensitive to $\beta$ (25\% lower

387 when setting $\beta$ at 1) especially in zones where absolute estimates made up an insufficient

388 proportion of the surface area of the zone.

389 As mentioned earlier, recruitment indices are of major importance for eel stock assessment.

390 As is the case with many stock assessment models, GEREM assumes that glass eel indices,

391 including commercial CPUE, are proportional to true abundance. However, Harley et al.

392 (2001) pointed out for many stocks that CPUE are not strictly proportionate to true abundance

393 but rather display a power relationship. The most common situation, called hyperstability, 
394

395

396 (Hilborn and Walters, 1992). However, the commercial CPUE used in this article, display

397 similar trends to other types of data (including scientific trap) which should not display

398 hyperstability. It has been observed at European level that most commercial CPUE collected

399 across Europe display a similar trend, despite very distinct fishery types between river

400 catchments. This trend is also similar to non fishery-based indices (ICES, 2010, p 201). In

401 view of this, we considered that hyperstability or hyperdepletion could be ignored in the

402 model.

403 Additionally, we carried out a simulation exercise where we fit the model to simulated

404 datasets to check that model performs adequately when assumptions are correct. Results are

405 presented in supplementary material

\subsection{Application to French eel sub-population}

408 The application of the model to France as a case study would appear especially relevant,

409 given that France is assumed to receive a significant proportion of population recruitment

410 (Lambert, 2008; Moriarty and Dekker, 1997). Estimating recruitment is of particular

411 importance in France, where glass eels are commercially fished - an industry which flourished

412 up until the early 2000s (Castelnaud, 2001). Data were available for 9 different river

413 catchments covering $47 \%$ of mainland France, and accounting for (according to the model)

414 about $35 \%$ of overall recruitment. The model estimates fit well with the different series, and

415 the trend is not sensitive to data uncertainty. Consequently, the estimated trend can be

416 considered reliable. The overall recruitment is not particularly sensitive to bias or uncertainty

417 in the data, even for the Somme catchment, where absolute estimates are based on an expert

418 assessment of exploitation rate. 
419 Using glass eel fishery data from 1993 and 1994, Moriarty and Dekker (1997) estimated that

420 recruitment in France, Spain, Portugal, and the Bristol Channel area in the United Kingdom

421 was around 538 tonnes, approximately $76 \%$ of total European recruitment, resulting in a glass

422 eel exploitation rate of $95 \%$ in this area. A similar approach to the same data, carried out by

423 Lambert (2008), led to a recruitment of approximately 1,500 tonnes in the same area, $74 \%$ of

424 total European recruitment, and an exploitation rate of $26 \%$. GEREM estimates for the same

425 period were similar, with a median of 1,490 tonnes in 1993 (credibility interval 784 to 5,020

426 tonnes), although this only applies to France.

427 The resulting exploitation rates were slightly lower, and recruitment estimates slightly higher

428 than estimates provided by a group of experts preparing French Management Plans in 2007

429 (unpublished data). There are two possible explanations for these differences. The first is that

430 the experts based their estimates on commercial catch data in commercially fished

431 catchments, and then had to extrapolate an overall exploitation rate for both fished and

432 unfished basins, possibly resulting in a small underestimation of abundance. The second is

433 that GEREM recruitment estimates were possibly slightly exaggerated for the Brittany EMU.

434 Catchments located on the west and north coasts of Brittany probably have smaller

435 recruitment levels (closer to those in the Seine-Artois zone) than catchments located on the

436 south coast (closer to Loire catchments). Since the Vilaine estuary, which is the only absolute

437 estimate series for this EMU, is located on the south coast, recruitment estimates in this zone

438 are probably over-optimistic.

439 On the contrary, the EDA model estimated that there were 6 times more silver eels in the

440 Seine Normandy EMU than in the Picardie EMU (Briand et al., 2015). The recruitment

441 estimated by GEREM for both of these EMUs combined is based on the data of the Somme,

442 which are probably lower than the potential number of recruits further west. In view of this,

443 recruitment in the Seine-Artois zone may have been underestimated.

444 For the Rhone-Mediterranea-Corsica estimates, it is important to take into account that 
445 Vaccares is a lagoon, and as such, the assumption we made relating to catchment surface area

446 and discharge relationship may not have been appropriate. New series and absolute

447 recruitment estimates could prove valuable in improving estimates made by the model.

448 The estimated overall recruitment displayed very large credibility intervals (Fig. 4). This can

449 be explained by several factors. Firstly, the uncertainty attached to $\beta$ due to the limited levels

450 of absolute recruitment series in a single zone is especially problematic, because the model is

451 highly sensitive to this parameter. Secondly, quantifications of uncertainty surrounding

452 available recruitment data series were not available. In view of this, we assumed that standard

453 deviations for each data series were independent (equations 5 and 6) and used uninformative

454 priors. However, it would be possible to use similar standard deviations for similar types of

455 data series (for example for data series provided by the same model). Model selection

456 criterion may be used to select the appropriate numbers of independent standard deviations. In

457 the future, if estimates of uncertainty on those data-series were provided, they could be used

458 to build more informative prior that would probably lead to smaller credibility intervals.

\subsection{Possible application to the whole stock}

461 The trend estimated by the model is very similar to the trend in the "Elsewhere-Europe" index 462 provided by the WGEEL (ICES, 2012a). With some minor modifications, GEREM could be 463 useful in taking into account differences in trends between the "Elsewhere-Europe" and North 464 Sea indices.

465 Instead of assuming constant proportions per zone through time (13), we can assume that 466 those proportions are time-dependent: $\left[p_{1}(y), \ldots, p_{n}(y)\right] \sim$ Dirichlet $\left(\lambda \cdot\left[p_{1}(y-1), \ldots, p_{n}(y-1)\right]\right)$. Assigning a high value to $\lambda$

468 (approximately 100) would be a suitable way to smooth inter-annual time-variations and 469 avoid erratic variations. The model would provide a single absolute recruitment estimate. 
470 Should this model be applied to the whole of Europe, the main limitation would once again be

471 the limited amount of absolute number estimates. Such an application would require

472 aggregation of EMUs into larger zones. ICES eco-regions (Celtic Sea, Atlantic coast,

473 Mediterranean area, North and Baltic Seas) would therefore appear a suitable spatial scale in

474 the future. Extension of the "index rivers" plan of action at European scale could be a

475 valuable source of information, as proposed by Dekker $(2002,2005)$ and ICES (2012b, 2014).

476 Standardisation of some monitoring programs throughout Europe could provide similar

477 catchabilities between recruitment indices so that they can be directly compared.

\subsection{Glass eel recruitment indices}

480 In the current version of the model, only recruitment indices collected in river catchments (i.e.

481 continental waters) are used. However, it would be possible to use recruitment series collected 482 at the zone level (i.e. marine waters). For example, when working at the European scale, the 483 recruitment indices provided by the ICES-International Young Fish Survey (Hagstrom and 484 Wickström, 1990) (part of the International Bottom Trawl since 1993) used by the WGEEL 485 (ICES, 2013), or the new Baltic eel recruitment estimates proposed by Westerberg and 486 Wickström (2014), may be used as zone abundance indices in the model. Tesch (1980) 487 proposed an index based on catches of leptocephali on the west of the European continental 488 shelf. Similarly, an index based on a survey in the Sargasso Sea may be used in the future as 489 an indicator of the population recruitment (Hanel et al., 2014; Hanel and Miller, 2014).

490 Regarding glass eel abundance estimates in rivers, Harrison et al. (2014) have recently

491 proposed an interesting review of the various methods that can be implemented to estimate 492 recruitment in estuaries. They underline the importance of an appropriate sampling design and 493 propose three main kinds of methods: combining trap and commercial catch data (Jessop, 494 2000), depletion methods (Tzeng, 1984) or models similar to those used in this study 
495 (Beaulaton and Briand, 2007; Bru et al., 2009). In some situations, when fishery exploitation

496 rates are close to 1, commercial landings can be good estimators of recruitment, such as in the

497 Vilaine estuary (Briand et al., 2003). Tag and recapture experiments may also be a relevant

498 method when recapture rate is significant (Briand et al., 2005; Dekker and van Willigen,

499 1997). In the future, the development of new video tracking methods (Delcourt et al., 2013)

500 may also provide relevant abundance estimates (Doehring et al., 2011; Grote et al., 2014),

501 although glass eels remain too small for those techniques.

502 In this paper, the model was applied to European eel, however the model is generic enough to

503 be applied to the two other temperate eels (Anguilla rostrata and Anguilla japonica) provided

504 enough data are available.

\section{Acknowledgments}

507 Authors would like to thank two anonymous referees for their suggestions and comments.

508 Data series used in this study were collected by Irstea, Institution Aménagement de la Vilaine,

509 Onema, Station Biologique de la Tour du Valat, Association Migrateurs Rhône Méditerranée,

510 Ifremer, tableau de bord Loire, Cellule Migrateurs Charente and Département halieutique

511 -Ecole Nationale Supérieure Agronomique de Rennes.

\section{$513 \quad 7 \quad$ References}

514 Als, T. D., Hansen, M. M., Maes, G. E., Castonguay, M., Riemann, L., Aarestrup, K., Munk, P., et al. 2011. All roads lead to home: panmixia of European eel in the Sargasso Sea. Mol Ecol, 20: 1333-1346.

517 Anonymous. 2010. Plan de gestion Anguille de la France - Application du règlement (CE) n¹100/2007 du 18 septembre 2007 - Volet national. Ministère de l’Ecologie, de 

et des Négociations sur le climat, Onema, Ministère de l'Alimentation, de l'Agriculture et de la Pêche. South European estuary (Oria Bay of Biscay). ICES Journal of Marine Science.

524 Beaulaton, L., and Briand, C. 2007. Effect of management measures on glass eel escapement. ICES Journal of Marine Science: Journal du Conseil, 64: 1402-1413.

526 Beaulaton, L., Briand, C., Lambert, P., Castelnaud, G., Drouineau, H., Chapon, P. M., Pénil, C., et al. 2014. Report on the eel stock and fishery in France 2013/2014. In Report of the Joint EIFAC/ICES Working Group on Eels (WGEEL), pp. 274-346.

Bertand, L. 2009. Etude de l'impact de la pêche à la civelle sur les estuaires de la Seudre et de la Charente dans le cadre du règlement européen R(CE) 1100/2007 sur l'anguille. UFR Sciences \& Techniques Côte Basque. 69 pp.

Briand, C. 2008. Dynamique de population et de migration des civelles en estuaire de vilaine. Rennes, ENSA. http://www.theses.fr/2009NSARH076 (Accessed 26 May 2015). Onema.

537 Briand, C., Bonhommeau, S., Castelnaud, G., and Beaulaton, L. 2008. An appraisal of historical glass eel fisheries and markets: landings,trade route and future prospect for

541 Briand, C., Buard, E., and Postic-Puivif, A. 2012. Modélisation de la capture de civelles dans management. In IFM 38th Annual Conference , 15/10/2007 - 18/10/2007, p. 21. Ed. l'estuaire de la Seudre par l'utilisation du modèle GEMAC. Modélisation de la capture de civelles dans l'estuaire de la Seudre par l'utilisation du modèle GEMAC. Traitement des données des saisons 2008-2009 et 2009-2010. http://www.fleuve- 
charente.net/bibliotheque/poissons-migrateurs/documents/files/rapport-sur-limpact-dela-peche-a-la-civelle-en-charente-et-en-seudre-via-limplementation-du-modelegemac-bertrand-loic.pdf/attachment_download/attachedFile.

548 Briand, C., Fatin, D., Feunteun, E., and Fontenelle, G. 2005. Estimating the stock of glass eels in an estuary by mark-recapture experiments using vital dyes. Bulletin Français de la Pèche et de la Protection des Milieux Aquatiques, 378-379: 23-46.

551 Briand, C., Fatin, D., Fontenelle, G., and Feunteun, E. 2003. Estuarine and fluvial recruitment of the European glass eel, Anguilla anguilla, in an exploited Atlantic estuary. Fish Manag Ecol, 10: 377-384.

554 Bru, N., Bouvet, J.-C., and Prouzet, P. 2006. Quantification par une méthode analytique de la biomasse saisonnière de civelles (Anguilla anguilla) dans l'estuaire de l'Adour et estimation du taux d'exploitation saisonnier de la pêche professionnelle de 1998 à 2005. Rapport Ifremer - projet Indicang http://www.ifremer.fr/ indicang/sites-

Bru, N., Prouzet, P., and Lejeune, M. 2009. Daily and seasonal estimates of the recruitment and biomass of glass eels runs (Anguilla anguilla) and exploitation rates in the Adour open estuary (Southwestern France). Aquatic Living Resources, 22: 509-523.

563 Burgers, H. E., Schipper, A. M., and Jan Hendriks, A. 2014. Size relationships of water discharge in rivers: scaling of discharge with catchment area, main-stem length and precipitation. Hydrological Processes, 28: 5769-5775.

566 Castelnaud, G. 2001. Localisation de la pêche, effectifs de pêcheurs et production des espèces amphihalines dans les fleuves français. Bulletin Français de la Pêche et de la

569 Castonguay, M., Hodson, P. V., Moriarty, C., Drinkwater, K. F., and Jessop, B. M. 1994. Is 
572 Cicotti, E. 2006. Nuovi metodi ecologici per la valutazione del reclutamento di ceche di anguilla europea (Anguilla anguilla L.) per la gestione sostenibile di questa risorsa. Relazione finale MiPAF, VI Piano Triennale n. $6^{\circ} 21$.

575 Crivelli, A. J., Auphan, N., Chauvelon, P., Sandoz, A., Menella, J.-Y., and Poizat, G. 2008. Glass eel recruitment, Anguilla anguilla (L.), in a Mediterranean lagoon assessed by a glass eel trap: factors explaining the catches. In Fish and Diadromy in Europe (ecology, management, conservation), pp. 79-86. Ed. by S. Dufour, E. Prévost, E. Rochard, and P. Williot. Springer Netherlands.

Dekker, W. 2000a. A Procrustean assessment of the European eel stock, 57: 938-947.

583 Dekker, W. 2000b. The fractal geometry of the European eel stock. ICES Journal of Marine Science: Journal du Conseil, 57: 109-121.

Dekker, W. 2002. Monitoring of glass eel recruitment. Netherlands Institute of Fisheries Research. report C007/02-WD.

Dekker, W. 2003. Did lack of spawners cause the collapse of the European eel, Anguilla anguilla? Fish Manage Ecol, 10: 365-376.

Dekker, W. 2005. Report of the Workshop on National Data Collection for the European Eel, Board of Fisheries, 282. 
39: 613-614.

598 Dekker, W., and van Willigen, J. 1997. Hoeveel glasaal trekt het IJsselmeer in? Verslag van een merkproef met glasaal te Den Oever in 1997. DIVO-DLO Rapport, C062/97. DLO-Rijksinstituut voor Visserijonderzoek.

601 Delcourt, J., Denoël, M., Ylieff, M., and Poncin, P. 2013. Video multitracking of fish behaviour: a synthesis and future perspectives. Fish and Fisheries, 14: 186-204.

603 Doehring, K., Young, R. G., Hay, J., and Quarterman, A. J. 2011. Suitability of Dual604 frequency Identification Sonar (DIDSON) to monitor juvenile fish movement at floodgates. N Z J Mar Freshwater Res, 45: 413-422.

606 Drouineau, H., Rigaud, C., Daverat, F., and Lambert, P. 2014. EvEel (evolutionary ecologybased model for eel): a model to explore the role of phenotypic plasticity as an adaptive response of three temperate eels to spatially structured environments. Canadian Journal of Fisheries and Aquatic Sciences, 71: 1561-1571.

613 Feunteun, E. 2002. Management and restoration of European eel population (Anguilla anguilla): An impossible bargain. Ecol Eng, 18: 575-591.

615 Feunteun, E., Castelnaud, G., Briand, C., Prouzet, P., Menella, J. Y., and De Roton, G. 2002. Monitoring of glass eel recruitment in France. In Monitoring of glass eel recruitment

620 Gelman, A., and Rubin, D. B. 1992. Inference from iterative simulation using multiple vol. 2B: Country Reports; Southern part, DEKKER W., pp. 179-217. Netherlands Institute of Fisheries Research, Ijmuiden, NLD. http://cemadoc.irstea.fr/cemoa/PUB00013143.

622 Grote, A. B., Bailey, M. M., Zydlewski, J. D., and Hightower, J. E. 2014. Multibeam sonar 
628 Hanel, R., and Miller, M. J. 2014. Changes in Abundance of Anguillid Leptocephali in the Sargasso Sea. Afs. https://afs.confex.com/afs/2014/webprogram/Paper16276.html (Accessed 2 October 2014).

Hanel, R., Stepputtis, D., Bonhommeau, S., Castonguay, M., Schaber, M., Wysujack, K., Vobach, M., et al. 2014. Low larval abundance in the Sargasso Sea: new evidence about reduced recruitment of the Atlantic eels. Naturwissenschaften, 101: 1041-1054. Hall, New York. 570 pp.

$$
\text { ICES CM 2010/ACOM:18. Hamburg. }
$$

ICES. 2012a. Report of the Joint EIFAAC/ICES Working Group on Eels (WGEEL). ICES CM 2012/ACOM:18. Copenhagen. / ACOM:62. Copenhagen.

646 ICES. 2013. Report of the Joint EIFAAC/ICES Working Group on Eels (WGEEL). ICES CM 2013/ACOM:18. Copenhagen.

648 ICES. 2014. Report of the Joint EIFAAC/ICES Working Group on Eels (WGEEL). ICES CM 
650 ICES. 2015. EU request on criteria for CITES non-detriment finding for European eel (Anguilla anguilla). In ICES Advice 2015, book 9. ICES. ICES. Species. Version 2014.2. http://www.iucnredlist.org.

654 Jessop, B. M. 2000. Size, and exploitation rate by dip net fishery, of the run of American eel, Anguilla rostrata (LeSueur), elvers in the East River, Nova Scotia. Dana, 12: 43-57.

Johnson, N. L., Kotz, S., and Balakrishnan, N. 1997. Discrete Multivariate Distributions. Wiley-Interscience. $328 \mathrm{pp}$.

Kettle, A. J., Asbjørn Vøllestad, L., and Wibig, J. 2011. Where once the eel and the elephant were together: decline of the European eel because of changing hydrology in southwest Europe and northwest Africa? Fish and Fisheries, 12: 380-411.

661 Koops, M. A., Young, A., and Cairns, D. K. 2014. Meta-Population Dynamics in the American Eel and the Importance of Larval Distribution. Afs. https://afs.confex.com/afs/2014/webprogram/Paper16645.html (Accessed 9 October 2014). partenariat Onema-Cemagref. http://cemadoc.irstea.fr/cemoa/PUB00028119.

$$
\text { 15: } 1-125 \text {. }
$$

670 Ohlssen, D. I., Sharples, L. D., and Spiegelhalter, D. J. 2007. Flexible random-effects models using Bayesian semi-parametric models: applications to institutional comparisons. Stat

673 Prouzet, P., Bouvet, J.-C., Bru, N., and Boussouar, A. 2007. Quantification de la biomasse saison-nière de civelles (Anguilla anguilla) dans l'estuaire de la Loire et estimation du 

2003 à 2005. Rapport Ifremer - projet Indicang http://www.ifremer.fr/indicang/boitebassins-versants/pdf/rapport-saison-bv-loire.pdf, Rapport Ifremer - projet Indicang http://www.ifremer.fr/indicang/boite-bassins-versants/pdf/rapport-saison-bv-loire.pdf.

R Development Core Team. 2011. R: A Language and Environment for Statistical Computing. http://www.R-project.org/.

Schmidt, J. 1923. Breeding places and migrations of the eel. Nature, 111: 51-54.

Sorensen, P. W. 1986. Origins of the freshwater attractant(s) of migrating elvers of the

\section{4} American eel, Anguilla rostrata. Environmental Biology of Fishes, 17: 185-200.

Stan Development Team. 2013. Stan: A C++ Library for Probability and Sampling, Version

$$
\text { 1.3. URL http://mc-stan.org/. }
$$

Tesch, F.-W. 1980. Occurrence of eel Anguilla anguilla larvae west of the European continental shelf, 1971-1977. Environmental Biology of Fishes, 5: 185-190. Tesch, F. W. 2003. The Eel. Blackwell Publishing.

Tzeng, W.-N. 1984. An estimate of the exploitation rate of Anguilla-japonica elvers immigrating into the coastal waters off Shuang-Chi River, Taiwan. Bulletin of the Institute of Zoology, Academia Sinica, 23: 173-180.

Vogt, J., and Foisneau, S. 2007. European river and catchment database, version 2.0 (CCM2) analysis tools. Report. Luxembourg : Publications Office of the European Union. http://www.envia.bl.uk//handle/123456789/4533 (Accessed 2 October 2014).

Vollestad, L. A. 1992. Geographic variation in age and length at metamorphosis of maturing European eel - Environmental effects and phenotypic plasticity, 61: 41-48.

Westerberg, H. 1998. Oceanographic aspects of the recruitment of eels to the Baltic Sea. Bulletin Français de la Pêche et de la Pisciculture: 177-185.

Westerberg, H., and Wickström, H. 2014. Baltic Eel Recruitment and Escapement; Quantitative Estimates from Survey Data. Afs. 

2014).

703 Wuenschel, M. J., and Able, K. W. 2008. Swimming ability of eels (Anguilla rostrata, Conger Biology, 154: 775-786.

706 Wu, J., and Levin, S. A. 1997. A patch-based spatial modeling approach: conceptual 


\section{$708 \quad 8$ Tables}

709 Table 1. Estimated parameters and corresponding prior and Rhat (Vogt and Foisneau, 2007)

\begin{tabular}{lcc}
\hline Parameters & priors & Rhat \\
\hline$\sigma_{R}:$ recruitment random- & $\sigma_{R}^{2} \sim$ InverseGamma $(0.01,0.01)$ & 1.001
\end{tabular}

walk standard-deviation

$$
\sigma_{U_{i}}: \text { standard-deviation of } \quad \sigma_{U}^{2} \sim \text { InverseGamma }(0.01,0.01)
$$

$\min 1.000$

observation for absolute index $i$

$\max 1.001$

$$
\sigma_{A I_{i}}: \text { standard-deviation of } \quad \sigma_{I A}^{2} \sim \text { InverseGamma }(0.01,0.01)
$$

$\min 1.000$

observation for relative index $i$

$\max 1.011$

$q_{i}$; catchability of relative

$$
\log \left(q_{i}\right) \sim \operatorname{Unif}(-10,10)
$$

$\min 1.000$

index $i$

$\max 1.002$

$R(1)$ : recruitment in first

$$
\log (R(1)) \sim \operatorname{Unif}(5,10)
$$

year

$$
\beta \text { : power parameter of the } \quad \beta \sim \operatorname{Unif}(0.01,2)
$$

relation between catchment

surface and proportion of the

recruitment

$p_{z} \quad$ Proportion of recruitment

in zone $z$

$$
\left[\begin{array}{c}
p_{1} \\
\vdots \\
p_{n b_{2}}
\end{array}\right] \sim \text { Dirichlet }\left[\begin{array}{c}
\alpha_{1} \\
\vdots \\
\alpha_{n b_{2}}
\end{array}\right]
$$

$$
\text { with } \quad \alpha_{1}=\ldots=\alpha_{n b_{z}}=\frac{1}{n b_{z}} \cdot \gamma \quad \text { and } n b_{z} \text { the }
$$

number of zones.

$$
\gamma \text { Dirichlet concentration } \quad \gamma \sim \operatorname{Unif}(0.3,10)
$$

parameter (a value below 1

leads to sparse distributions

while a value above 1 leads to

dense distributions) 
(C). This manuscript version is made available under the CC-BY-NC-ND 4.0 license http://creativecommons.org/licenses/by-nc-nd/4.0/

711 Table 2. Zone characteristics (Vogt and Foisneau, 2007)

EMU

Catchment area $\left(\mathrm{km}^{2}\right)$

Seine - Artois

114,293

Bretagne

30,561

Loire

127,813

Garonne

97,340

Rhone - Mediterranea - Corsica 129,586

Adour

20,228

712 
713 Table 3. Recruitment data series ( type $\mathrm{I}=$ index, $\mathrm{A}=$ absolute). Absolute abundance indices

714 are either provided in catchments where exploitation rates are closed to 1 (Briand et al., 2003)

715 or by model estimations (Beaulaton and Briand, 2007; Prouzet et al., 2007). In the Bresle

716 River, the index is based on a trap device that collects recruits composed of a few glass eels

717 and mostly pigmented elvers.

\begin{tabular}{|c|c|c|c|c|c|c|c|}
\hline \multicolumn{4}{|c|}{ Catchment characteristics } & \multicolumn{4}{|c|}{ Recruitment indices } \\
\hline Zone & Catchment & $\begin{array}{l}\text { Area } \\
\left(\mathrm{km}^{2}\right) \\
(\% \text { zone })\end{array}$ & $\begin{array}{l}\text { River } \\
\text { length } \\
(\mathrm{km})\end{array}$ & $\begin{array}{l}\text { Index } \\
\text { short } \\
\text { name }\end{array}$ & Type & $\begin{array}{l}\text { Extent } \\
\text { (missing } \\
\text { data) }\end{array}$ & Ref \\
\hline Seine - Artois & Bresle & $\begin{array}{l}748 \\
(0.6 \%)\end{array}$ & 72 & Bres & I & $\begin{array}{l}1994- \\
2010\end{array}$ & $\begin{array}{l}\text { (Beaulaton et al., } \\
\text { 2014) }\end{array}$ \\
\hline Seine - Artois & Somme & $\begin{array}{l}6,550 \\
(5.7 \%)\end{array}$ & 245 & Somme & A & $\begin{array}{l}1992-2012 \\
\text { (1) }\end{array}$ & \\
\hline Bretagne & Vilaine & $\begin{array}{l}10,500 \\
(34 \%)\end{array}$ & 218 & Vil & A & $\begin{array}{l}1971- \\
2011\end{array}$ & $\begin{array}{l}\text { (Beaulaton et al., } \\
\text { 2014) }\end{array}$ \\
\hline Loire & Loire & $\begin{array}{l}117,000 \\
(92 \%)\end{array}$ & 1013 & LoGERM & $\mathrm{A}$ & $\begin{array}{l}2004- \\
2006\end{array}$ & $\begin{array}{l}\text { (Prouzet et al., } \\
\text { 2007) }\end{array}$ \\
\hline Loire & Loire & & & Loi & I & $\begin{array}{l}1950- \\
2008\end{array}$ & $\begin{array}{l}\text { (Beaulaton et al., } \\
\text { 2014) }\end{array}$ \\
\hline Loire & $\begin{array}{l}\text { Sèvre } \\
\text { Niortaise }\end{array}$ & $\begin{array}{l}3,650 \\
(2.9 \%)\end{array}$ & 159 & SevN & I & $\begin{array}{l}1962- \\
2008(25)\end{array}$ & $\begin{array}{l}\text { (Beaulaton et al., } \\
\text { 2014) }\end{array}$ \\
\hline Garonne & Charente & $\begin{array}{l}9,855 \\
(10 \%)\end{array}$ & 381 & ChGEMA & A & $\begin{array}{l}2007- \\
2008\end{array}$ & (Bertand, 2009) \\
\hline Garonne & Seudre & $\begin{array}{l}855 \\
(0.9 \%)\end{array}$ & 68 & SeGEMAC & & $\begin{array}{l}2007- \\
2008\end{array}$ & $\begin{array}{l}\text { (Bertand, 2009; } \\
\text { Briand et al., } \\
\text { 2012) }\end{array}$ \\
\hline Garonne & Garonne & $\begin{array}{l}78,870 \\
(81 \%)\end{array}$ & 647 & GiGEMAC & $\mathrm{A}$ & 1999 & $\begin{array}{l}\text { (Beaulaton and } \\
\text { Briand, 2007) }\end{array}$ \\
\hline Garonne & Garonne & & & $\mathrm{GiCP}$ & I & $\begin{array}{l}1961- \\
2008(1)\end{array}$ & (Beaulaton et al., \\
\hline Garonne & Garonne & & & GiSc & $\mathrm{I}$ & $\begin{array}{l}1992- \\
2013\end{array}$ & $\begin{array}{l}\text { (Beaulaton et al., } \\
\text { 2014) }\end{array}$ \\
\hline Adour & Adour & $\begin{array}{l}16,880 \\
(83 \%)\end{array}$ & 309 & AdGERM & AA & $\begin{array}{l}1999- \\
2005\end{array}$ & $\begin{array}{l}\text { (Bru et al. } \\
\text { 2006) }\end{array}$ \\
\hline Adour & Adour & & & $\mathrm{AdCP}$ & I & $\begin{array}{l}1966- \\
2008(6)\end{array}$ & $\begin{array}{l}\text { (Beaulaton et al., } \\
\text { 2014) }\end{array}$ \\
\hline $\begin{array}{l}\text { Rhone - } \\
\text { Mediterranea } \\
\text { - Corsica }\end{array}$ & Vaccarès & $\begin{array}{l}6.5 \\
(<0.1 \%)\end{array}$ & 245 & Vaccares & $\mathrm{A}$ & $\begin{array}{l}2004- \\
2011\end{array}$ & $\begin{array}{l}\text { (Crivelli et al., } \\
\text { 2008) }\end{array}$ \\
\hline
\end{tabular}




\section{Figures}

720 Fig. 1. Maps of considered zones (solid lines indicates EMUs border)

721 Fig. 2. Estimated (black solid lines) and observed (grey line and points) absolute estimates.

722 Dashed lines represent $95 \%$ credibility intervals for $\mu_{U_{i, c}}$ while solid lines represent the 723 median.

724 Fig. 3. Estimated (black solid lines) and observed (grey line and points) relative indices.

725 Dashed lines represent $95 \%$ credibility intervals for $\mu_{I A_{i, c}}$ and solid lines represent the 726 median

727 Fig. 4. Estimated French glass eel recruitment in tonnes (bottom panel) and in log-scale (top 728 panel). Solid line indicates the median while dashed lines represent the corresponding 729 credibility interval (95\%). Darker grey line represents Elsewhere-Europe WGEEL index

730 (ICES, 2013) while light grey line represents the catches estimated by Briand et al. (2008).

731 Fig. 5. Estimated proportions of the recruitments in the different EMUs.

732 Fig. 6. Recruitment (median) estimated by the model when fitting the model on altered

733 datasets according to S1 (left panel) and S2 (right panel).

734 Fig. 7. Zone recruitments estimated by the model for the last year when the model is fitted on 735 altered datasets according to S1 (top panel) and S2 (bottom panel). Bars represent the median

736 while vertical segments represent the $97.5 \%$ quantile of the a posteriori distributions

737 Fig. 8. Medians (circles) and 2.5 and $97.5 \%$ quantiles (segments) of $\beta$ estimated by the model 738 when the model is fitted on altered datasets according to S1. 